\title{
ATIVIDADES SECRETAS EM NOITES SOMBRIAS: MEMÓRIAS DO UNIVERSO DOS GAROTOS DE PROGRAMA ${ }^{1}$
}

\author{
Francisco Ramos de Farias ${ }^{2}$
}

\section{Resumo}

Este estudo destina-se a explicar as relações entre dois tipos de atividades sexuais, caracterizadas pela ação de um homem em determinados lugares para oferecer e prestar serviços sexuais, dispondo do corpo para aluguel temporário, identificado como proprietário, e a de outro que frequenta esses lugares em buscas desses serviços, identificado como inquilino. Ambos celebram um contrato determinado pelo proprietário, restando ao inquilino aceitá-lo ou não, mas jamais modificar quaisquer cláusulas. A ação desses homens e suas consequências relatadas pelo proprietário, em cinco encontros, anotada pelo pesquisador, constituem uma escrita sobre as várias ocorrências que têm lugar na calada das noites em espaços de grandes cidades onde ocorre a prostituição masculina. Conclui-se que o contrato entre ambos não os transforma em aliados devido à assimetria da relação que se estabelece entre duas posições subjetivas diferentes e que o proprietário utiliza-se de subterfúgios para negar a sua homossexualidade.

Palavras-chave: Homossexualidade. Prostituição. Memória social. Crime. Desejo.

\section{Circunscrição da questão}

Um dos cenários de grande repercussão, nas últimas décadas do século passado, concerne às práticas relacionadas à sexualidade homoerótica. Nessa época, certa liberalização em relação à homossexualidade e a sua exclusão da rubrica de doença a retirou das sombras do não-dito. Nos grandes centros urbanos, o fenômeno alcançou expressões nunca dantes imaginadas: passeatas do orgulho gay e o surgimento da prostituição viril. Um novo personagem busca um lugar no contexto das práticas sexuais: o garoto de programa, designação utilizada para o prostituto viril que presta serviço, quase sempre, a homens. Essa terminologia tem uma relação estreita com outra da década de 1960: o michê; figura

\footnotetext{
${ }^{1}$ Esta pesquisa foi realizada no período de 1994 a 1998, época em que ainda não havia exigência de parecer de Comitê de Ética para construção de dados. Faz parte de um projeto, financiado pelo CNPq, intitulado: Do contrato de locação à morte.

${ }^{2}$ Doutor em Psicologia pela Fundação Getúlio Vargas, Rio de Janeiro, RJ, Brasil. Professor adjunto da Universidade Federal do Estado do Rio de Janeiro, Rio de Janeiro, RJ, Brasil. Consultor Ad Hoc da Fundação de Amparo a Pesquisa do Estado do Rio de Janeiro. E-mail: frfarias@uol.com.br
} 
reconhecidamente homossexual que mantinha relacionamentos sexuais remunerados. Sem adentrar na questão da prostituição viril pelo viés histórico, nem nas condições que produziram os personagens michê e garoto de programa, pretende-se refletir sobre a construção da memória social relativa às atividades praticadas mediante a celebração de um contrato para a realização de serviços sexuais entre homens e, igualmente, analisar os seus desdobramentos no âmbito de práticas sexuais homoafetivas. Não se pretende traçar a matriz histórica do advento desses personagens, mas sim enveredar por uma trilha para entender um contrato firmado entre dois homens, para fins de práticas sexuais, com justificativas diferentes para ambos, pelo menos no que tange ao significado dessas práticas: um deles, o garoto de programa dispõe de seu corpo para aluguel, admitindo tratar-se de um serviço prestado, e o outro, o cliente procura satisfação sexual, pagando pelo "serviço". Os termos garoto de programa e cliente são um artifício utilizado, neste estudo, para circunscrever os protagonistas desse tipo de práticas sexuais em função de uma interpretação que considera questões de natureza econômica, já que previamente há uma negociação estabelecida por um contrato para prestação de serviços.

O aparecimento do personagem, o garoto de programa, exposto em vias públicas na condição de objeto de consumo, atende à lógica que rege as ações humanas na atualidade e, segundo Lumbroso (2008), está ancorado em duas circunstâncias: por um lado, em modos de proceder decorrentes da revolução dos costumes sexuais e, por outro, responde ao apelo social relativo às ofertas disponibilizadas em meios midiáticos. No cenário da contemporaneidade, a busca por tais serviços pode ser compreendida em termos do enquadramento a circunstâncias de consumo e à transgressão a determinados costumes, se considerarmos que determinados homens, ao firmarem um contrato para fins de práticas sexuais, desviam as ações para outras finalidades como extorsões, roubos, uso de substâncias químicas, assassinatos.

O móbil para as práticas sexuais concerne aos atrativos do objeto cativante representado pelo corpo jovem e todas as suas indumentárias. O encanto advindo do corpo do garoto de programa deixa, em segundo plano, as tradições estabelecidas do vínculo amoroso, contrapondo-se também às convenções relacionadas à categoria de gênero assimilada à finalidade da reprodução. A conformação desse modelo tem, como consequência, a expressão de uma busca 
direcionada à virilidade; um padrão idealizado de homem que povoa o imaginário social. Para atingir essa condição

no mercado do sexo organizado, os garotos possuem jornada de trabalho regular, programa sexual tabelado e pagam pelo ponto de prostituição e pelos investimentos no corpo, como, por exemplo, anabolizantes, estimulantes sexuais (ALVES, 2010, p. 35).

As transformações corpóreas encaixam-se em um estereótipo de macho ideal: ausência de indício feminino. Esse assim chamado homem de verdade enquadra-se em um modelo de homem supostamente heterossexual, pois os garotos de programas, são homens que "oferecem no mercado da prostituição uma performance erótica viril” (NARDI, 2010, p. 225).

As atividades dos garotos de programas são temas de reflexão complexa que encerra, pelo menos, dois paradoxos. Em primeiro lugar, esse segmento da prostituição viril, em sua grande maioria, não se considera homossexual, nem admite corresponder àquilo que Parker (2004) denomina homens que fazem sexo com homens, uma vez que, em suas crenças, seus clientes é que são homossexuais. Apenas admitem que exercem determinadas práticas sem qualquer envolvimento afetivo. Possivelmente, a representação de si mesmos é a de um técnico que põe em funcionamento dados dispositivos para a realização de um ato sexual. Há nisso, claramente, uma disjunção entre a prática sexual desencadeada pelo desejo e a que decorre de um pagamento que não envolve qualquer demonstração afetiva pelo garoto de programa. Essas práticas acontecem em contextos culturais distintos, onde realidades socioeconômicas regem o contrato, cobrindo diferentes nuanças identitárias. Quase sempre os garotos de programa são oriundos de classes sociais menos favorecidas em comparação com os clientes. Há, em muitos garotos de programas, uma recusa em admitir que suas práticas sexuais inserem-se na rubrica de uma relação homoerótica. Essa recusa é justificada, por eles próprios, pelo não envolvimento afetivo e pelo fato de que apenas prestam serviços, o que parece ser um atrativo para aqueles que o procuram (PERLONGHER, 2008). Em segundo lugar, parece haver também uma ausência de solidariedade entre os garotos de programa, dando a impressão da criação de uma zona social onde o controle é frouxo, mas não completamente suspenso, sendo também comum o clima de competição e desconfiança. Nesse cenário, os atores 
encontram-se para estabelecer contratos informais, visando à obtenção de satisfação: o garoto de programa, do dinheiro, e o cliente, do sexo. Contudo, há, nesse espaço, tensões, devido sua configuração ser a de uma territorialidade móvel, em fluxo constante, em razão das negociações do corpo em cifras econômicas. $O$ que é mostrado para aluguel e o que é pago não é simplesmente um corpo qualquer, mas um corpo marcado por insígnias que, convencionalmente, sinalizam a masculinidade: dorsos produzidos em academias de ginásticas remontando aos tipos gregos de outrora; posturas corporais típicas; gestos que retratam modos de ser supostamente viris, copiados de trabalhadores da construção civil, estivadores, militares, caminhoneiros, entre outros. Há nisso a adoção de um estilo que contraria o modelo tradicional, pois

se antes o corpo estava subjugado, restrito e limitado na satisfação de seus desejos, agora parece redescobrir-se pelo viés do consumo. O corpo tornase símbolo de status social, moeda importante para troca no mercado simbólico (BUSSINGER, 2011, p. 96).

Nesse sentido, produz-se um corpo recoberto de indumentárias e alinhado em gestos para a competição. Os corpos circulantes que mais se aproximam do modelo de virilidade são os mais procurados.

Os sinais que valorizam o corpo, juntamente com a idade do garoto de programa, refletem-se em condições de negociação do serviço a ser prestado: quanto mais atributos supostamente viris, maior será o preço a ser cobrado, visto que "o sujeito masculino só se manifesta para originar significados e, por meio disso, significar" (BUTLER, 2010, p. 74). Sendo assim, toda a transformação corpórea visando à aquisição de atributos justifica-se pela alta rentabilidade. Para isso são criadas senhas de participação no gueto ou "mercado homossexual que se encontra encravado no seio da região moral marginal que não tem apenas consequências em termos da paisagem urbana como também da paisagem relacional" (PERLONGHER, 2008, p. 50). Daí forja-se um espaço micro onde se processa a interiorização de dados preceitos de pertinência, reproduzindo, até certo ponto, relações sociais, mas sem que funcione em termos de resistência aos costumes dominantes. Na verdade, é um tipo de funcionamento que responde a determinadas demandas da sociedade, com extensões a casas de massagem, a termas, aos serviços em domicílio anunciados em jornais. Por isso, a via pública deixa de ser o 
único local de exposição: o gueto amplia-se para lugares privados. Em ambos os espaços, "a lógica homossexual responde, com efeito, a um duplo movimento. A especialização: sabe-se cada vez melhor o que se quer em determinado momento e a diferenciação: buscam-se práticas cada vez mais diferenciadas" (POLLAK, 1986, p. 60).

\section{Relevância do fenômeno em estudo}

A finalidade dessa investigação é explicar quais mecanismos acionam o garoto de programa a prestar serviços sexuais utilizando-se de dois argumentos: a condição econômica e a existência de clientes a procura de sexo com homens. Essas justificativas são consideradas argumentos para a recusa de seu desejo em ter relações sexuais com homens. Na verdade, a assunção de tais crenças serve de medidas protetoras juntamente com o fato para alguns garotos de programa que são casados e gostam de relações sexuais com mulheres, o sexo que praticam com homens não deve ser considerado homossexualidade. Tudo indica que para os garotos de programa ser homossexual é gostar e desejar ter relações sexuais com homens. Certamente o temor em admitir o desejo sexual por homens advém do fato de que, segundo Mott (1996, p. 103), "os homossexuais representam o segmento mais discriminado e odiado pelos brasileiros, sendo muitas vezes rejeitados até por entidades defensoras dos direitos humanos". Provavelmente, a disseminação do ódio e reprovação à homossexualidade pode ter um efeito direito em alguns homens que se valem de artifícios para afirmarem-se não homossexuais, mesmo tendo relações sexuais com homens. Porém essa não é a única interpretação possível. Além do mais, existem criminosos que se utilizam da camuflagem de garotos de programa para praticar roubos, extorsões, exposição do cliente a situações constrangedoras pela ameaça de divulgação em jornais e até em circunstâncias nas quais determinados agentes policiais, em desvio de suas funções, firmam pactos que configuram verdadeiras montagens perversas (FARIAS, 1995). Como se pode observar, o campo dessas práticas é bem complexo. A possibilidade de exposição de um homem de classe média aos meios de comunicação, como também ao aparato policial tem efeitos diferenciados. Para o garoto de programa, uma situação dessa natureza pode resultar em negociações mais vultosas financeiramente do que a decorrente do serviço sexual. Então, as ameaças fazem parte do contrato, porém 
de forma implícita sendo enunciadas em momentos apropriados. Assim, as engrenagens são construídas como métodos de gerenciamento para as circunstâncias envolvidas em um tipo de complemento de renda, mas que escondem um objetivo principal embutido no pensamento de que aquele que não dispõe de bens deve retirá-los de quem os possui, pelos mais diversos métodos. Esse tipo de crença indica a presença de uma lógica que evoca o pensamento de Sade (2008, p. 143) de que "havia um povo que não punia o ladrão, mas quem se deixasse roubar, a fim de ensinar-Ihe a cuidar melhor de suas propriedades". Em certo sentido, o garoto de programa culpabiliza o cliente por dispor de condições econômicas para pagar pelo uso de seu corpo, podendo chegar mesmo a odiá-lo por isso. Para o cliente, a exposição pública de sua homossexualidade e também de sua condição social podem ter consequências bem desagradáveis, como separação conjugal ou aviltamento por parte de familiares, além, evidentemente, das repercussões, na esfera policial, desencadeadas pelo encontro com o garoto de programa que, quase sempre, é desconhecido do cliente. Muitas vezes, são celebrados dois contratos: um com o cliente e outro com um policial ou um bandido que se apresenta como agente da polícia. Obviamente o cliente desconhece o contrato que é celebrado entre o garoto de programa e esse agente. Não obstante, em algumas situações o contrato é firmado com policiais. Nessas circunstâncias, o garoto de programa e os policiais agem de forma desviante de suas funções, intimidando o cliente em termos de iminência da prática de um crime de atentado ao pudor ou ante a situação da menoridade do garoto. Estão certos de que contam com o ódio disseminado, no imaginário social, aos homossexuais, bem como com a condenação por diversos setores entre os quais se destaca o domínio das práticas religiosas, entre outros.

\section{0 campo de investigação}

Considerando as peculiaridades do universo dessas práticas, este estudo, realizado na cidade do Rio de Janeiro, destina-se a explicar a dinâmica relacional entre o garoto de programa e o cliente, engajados em atividades sexuais. Pretendese construir teias de memória circunscritas em função da diferenciação social estabelecida, principalmente, pelo poder econômico, caracterizado pela lógica da oferta do corpo e pagamento, pela sua utilização. Trata-se de um contexto de ações que envolve dois protagonistas em circunstâncias bastante assimétricas: de um 
lado, um homem apresenta-se em determinados lugares com a finalidade de oferecer e prestar serviços sexuais, o que, na atualidade, sofreu um certo declínio devido a utilização da internet para divulgação e a criação de espaços privados. Em quaisquer das situações em que seja feita a oferta do serviço (espaços públicos, privados, jornais ou internet) tem-se o garoto de programa dispondo de seu corpo para aluguel. Do outro lado, outro homem frequenta tais lugares, em busca desses serviços, disposto a pagar pelo serviço sexual prestado. Essas operações econômicas têm lugar nas grandes cidades; não ocorrem no vazio, pois seguem um roteiro cujo enredo caracteriza um possível lugar discursivo. Esses dois homens estabelecem um tipo de transação seguindo critérios vigentes no contexto econômico de disponibilização de bens para consumo, onde o corpo é transformado para alcançar altas cifras. Tal transação é selada mediante um contrato de locação ditado pelo garoto de programa, seguindo as normas vigentes no lugar onde é firmado. Embora aconteça em sombras noturnas, esse contrato reproduz o modelo de prestação de serviço, porém nele são prescritas normas que delimitam o encontro sexual entre homens de idades, origens étnicas e condições econômicas diferentes. Ao cliente resta a alternativa de aceitar ou não, mas jamais de modificar quaisquer de suas cláusulas. Porém, como é o detentor econômico, pode fazer ofertas, em termos da variação dos serviços desejados. Em circunstâncias relativas ao procedimento do estudo da situação em campo, um dos protagonistas, o garoto de programa, informou que o cliente, por dispor de dinheiro, pode sugerir a ampliação de serviços, cabendo a aceitação ou não de sua parte, mesmo que isso signifique não fazer o programa. Foi informado também que alguns garotos de programa apresentam uma tabela de serviços com variações de preço, deixando a opção de escolha. Não obstante, o contexto no qual um homem oferta serviços sexuais e outro paga configura a "decadência em termos do valor erótico: como seu corpo tem-se desvalorizado, precisaria compensar essa perda de valor de troca com um pagamento em dinheiro" (PERLONGHER, 2008, p. 145). Essa é uma interpretação a ser problematizada em relação à inversão de valores das últimas duas décadas do século passado. Se, por um lado, o garoto de programa apresenta uma exuberância de sinais de masculinidade (o que não quer dizer que seja uma compensação pela perda do valor erótico), socialmente reconhecidos, o cliente, por outro, expressa a perda desses mesmos indícios, especialmente, pela construção social de que a idade retira os atrativos do corpo, colocando-se em uma posição de 
inferioridade, às vezes, compensada pelo dinheiro. Então, no caso do cliente, pode ser uma compensação aos sinais de decrepitude corpórea, principalmente por aceitar que o corpo envelhecido não pode ser objeto de desejo.

O garoto de programa apresenta-se como um técnico especializado em prestar serviços, munido da crença de que dispõe de atrativos viris desejados e também de que é um expert naquilo que faz. Para alcançar essa condição, produz em si mesmo uma transformação: negar que sua prática é sexual, pois só admite ser sexo quando há envolvimento afetivo e que, por gostar somente de mulheres, o sexo que pratica com homens encontra-se fora do âmbito de seu desejo. Por isso, considera o que faz apenas um serviço solicitado pelo cliente. Tais crenças são manobras para elevar os valores cobrados pelos serviços. Revestido da condição de técnico, dispõe-se a executar, com esmerada perfeição, as regras estabelecidas no contrato, muitas delas nem sempre explicitadas, mas que julga ser de ciência do cliente. Além disso, parte do pressuposto de que esse tem a obrigação de saber dos possíveis desdobramentos do encontro como roubo, maltrato, aviltamento e morte. Não que isso seja uma regra nas ações dos garotos de programa, embora a mídia, constantemente, vincule a prostituição ao crime (ARRUDA, 2001). Fica então uma questão: são garotos de programas ou assaltantes que se valem da condição de garotos de programa para praticar roubos, assaltos, extorsões?

Geralmente, o garoto de programa sustenta a crença de que a exposição de seu cliente e sua vulnerabilidade (os lugares de prostituição são reconhecidas por serem regiões violentas) devem fazer parte de seu conhecimento como também, se está a busca de tais aventuras, é porque assim o deseja. O denominador comum que marca o encontro desses dois homens consiste na possibilidade de o garoto de programa oferecer alguma coisa ao cliente: possivelmente um tipo de masculinidade construída segundo insígnias relacionadas a um estereótipo de virilidade (STOLLER, 1993). Contudo, não devemos esquecer que estamos no âmbito de práticas sexuais de natureza homoerótica com uma caracterização particular. Em princípio, constatase $\mathrm{o}$ isolamento do ato sexual em uma modalidade específica cuja finalidade primeira é pagar e receber pelo uso momentâneo do corpo. Também são colocados em suspensão os vetores relacionados ao espaço, os territórios de exibição são flutuantes, e ao tempo: existe variação na hora de prestação do serviço: hora de almoço e noite. Desse modo, ocorre 
a restrição a um mínimo de ritos de preparação ao ato, o desenvolvimento de um sistema de comunicação que permita essa minimização ao mesmo tempo em que eleve a um nível máximo os rendimentos orgásticos (POLLAK, 1986, p. 57).

Parece que as ações seguem uma lógica estabelecida a priori, que funciona apesar da mobilidade do território de encontro e das flutuações temporais nas quais ocorrem as práticas sexuais.

Tendo em vista as considerações expostas, algumas questões se colocam: a) como os atores dessa encenação particular apresentam-se ou se autorrepresentam respectivamente em termos da prostituição? b) quais filigranas de memória são potencializadas no encontro? e c) qual o estatuto discursivo, nesse contrato, que tem valores diferentes para ambos? Para refletir sobre essas indagações este estudo pautou-se em cinco encontros realizados nos percursos de exibição de um garoto de programa, de 21 anos de idade, fuzileiro naval, filho único, morador de um município do estado do Rio de Janeiro. Os encontros registrados mediantes anotações foram realizados em momentos em que o garoto de programa encontrava-se fora de suas atividades militares. Não houve autorização para a gravação de vozes: o consentimento restringiu-se apenas a registros escritos. É conveniente assinalar que esse garoto de programa fazia questão de mencionar sua identidade militar, embora adotasse um nome fictício. Essa estratégia de anonimato logo fracassava quando seus clientes o encontravam uniformizado e descobriam seu verdadeiro nome, pelo menos, o nome que o identificava como fuzileiro.

As estórias desse garoto de programa, produzidas em diferentes momentos, são objeto de análise, cujas nuanças investigadas focalizam, por um lado, as interações verbais face a face e, por outro, o conteúdo implícito nos relatos. Mediante a interpretação do material apresentado na forma de conteúdo manifesto, configurou-se dois registros de memória condicionados em arquivos diferenciados (RIESSMAN, 2009). A utilização dos estudos da narrativa tem por objetivo identificar os mecanismos linguísticos recorrentes e os acidentes produzidos quando o sujeito dispõe da linguagem para contar estória e assim traçar o enredo de sua existência. Com isso constata-se a importância que a narrativa desempenha na vida das pessoas, quer dizer: por que alguém se dispõe a contar uma estória ou mesmo sua própria estória? Geralmente, o homem vale-se dos recursos da linguagem para relatar fatos dos quais foi protagonista no intuito de produzir significações para os 
mesmos e também relatar fatos presenciados na condição de testemunha em um processo de reconstituição. Ainda ocupa-se de contar estórias, pois além dessa nuança da existência ser a forma encontrada de perpetuar a realidade social, é fundamentalmente a possibilidade de criá-la e, até certo ponto, de manipulá-la. Ressalte-se que o homem, ao se fazer presente no enredo produzido pela fala à medida que constrói estórias sobre sua vida, vale-se de recursos mnêmicos de seu legado cultural no sentido de construir seus arranjos subjetivos, ou seja, "somente há um sujeito que fala para um outro sujeito que fala, pois o sujeito é somente a emergência do ser de uma propriedade da linguagem" (SAFOUAN, 2001, p. 77). Daí o encontro entre pesquisador e garoto de programa ser considerado uma via possível de significação, visto que quem entra em campo para contar estórias ou mesmo suas estórias é constantemente afetado por aquilo que narra como também o é aquele que se coloca na posição de interlocutor. Cabe advertir que o foco da investigação é a relação de prestação de serviços de um homem a outro, o que é encenado nas estórias tecidas em narrativas. Por esse motivo, este estudo pretende demonstrar a função da narrativa na caracterização do universo do garoto de programa no contexto de sua sexualidade, bem como o modo como avalia discursivamente o papel que desempenha no contrato firmado para prestação de serviços sexuais e finalmente, de quais recursos de memória utiliza-se para tecer a estória apresentada em suas narrativas. Em função da interação particular entre o pesquisador e o garoto de programa envereda-se pelo viés da narrativa como a estratégia que retrata o universo de práticas sexuais na prostituição masculina. Cabe ressaltar que o contrato firmado consistiu em um acordo de trabalho visando o entendimento das razões que determinam, para o garoto de programa, a escolha e a utilização de mecanismos para justificar a prática sexual com homens.

\section{Metodologia}

O corpus de dados decorre dos encontros realizados em um ambiente de prostituição masculina, nas proximidades do prédio do MEC, da Santa Casa de Misericórdia, do Aeroporto Santos Dumont e, principalmente, nas escadas da Igreja Santa Luzia; espaços do centro da cidade do Rio de Janeiro. O registro narrado decorre de anotações do pesquisador acerca do texto produzido pelo garoto de programa. A distância temporal da realização dos encontros (mais de uma década) e 
a sua divulgação justificam-se pela preservação da identidade do garoto de programa. As transcrições reproduzem os relatos, sem qualquer incursão interpretativa do pesquisador. Tal procedimento foi adotado em razão da dificuldade inerente à situação socialmente atípica não institucionalizada em que os informantes $^{3}$ estão, certamente, muito preocupados em não serem identificados, seja por imagens ou rastros vocais, pois alguns são estudantes universitários; outros têm emprego fixo; outros são casados e têm filhos e também alguns estão na iminência de se casarem ou de procurar trabalho com carteira assinada. $O$ garoto de programa desse estudo é jovem, de boa aparência e apresenta os atributos físicos que são, convencionalmente, necessários ao desempenho da função, além de ser militar na época em que foram realizados os encontros. Atualmente é pastor de uma igreja evangélica, embora admita ainda praticar sexo por dinheiro. O material do campo configura-se em narrativas obtidas por meio de estratégias que provocassem o seu surgimento, pela explanação sobre o objeto da pesquisa; pelas formulações de perguntas e também pela disponibilidade do surgimento de produções espontâneas apresentadas como explicações e justificativas empregadas pelo garoto de programa, em relação ao seu universo subjetivo, deixando transparecer pontos de vista, crenças, atitudes, valores e convicções que, em conjunto, servem como pretextos para o engajamento na atividade de prostituição, bem como, mascarar a posição subjetiva concernente à prática sexual com homens e, ainda, negar a satisfação sexual. Sem haver um roteiro prévio a ser seguido, os cinco encontros ocorreram em contextos dos quais são extraídos quatro eixos de análise e interpretação das narrativas, visando: a) descrever atitudes, sentimentos e valores do garoto de programa consigo mesmo e os valores, as atitudes e os sentimentos em relação ao cliente e, b) demonstrar os motivos que justificam o engajamento nesse tipo de atividade.

\section{Análise e interpretação}

As reflexões seguintes resultam da análise do material de um protagonista em uma postura interativa com o pesquisador. Vale lembrar que a entrada no campo para registro dos dados decorreu de um trabalho de ambientação e negociações

\footnotetext{
${ }^{3}$ Como esclarecimento vale salientar que foram entrevistados mais de dez garotos de programa, embora para o estudo em tela foi escolhido as narrativas de um.
} 
necessárias quanto à segurança e o estabelecimento de confiança com os garotos de programa para ser possível a investigação. Houve resistência deles para participar da pesquisa, pois muitos alegavam que aquele era um ambiente de trabalho e que não poderiam perder tempo com pesquisa, a não ser que houvesse pagamento, o que não aconteceu. Cabe informar que o participante, voluntariamente, decidiu falar de si e de suas atividades. Das narrativas foram selecionadas passagens para a análise. A construção de quatro eixos interpretativos decorreu de evidências expressas no material que permitiram esse tipo de alinhamento. Poderiam ser mais de quatro, mas esses apresentam coerência com as metas preconizadas na reflexão sobre a questão em estudo.

\subsection{Eixo 1: Atividade garoto de programa}

Pesquisador: "Eu tou fazendo uma pesquisa sobre esse negócio de homens que transam por dinheiro, quer dizer, esses rapazes que cobram para transar".

Garoto de programa: "Ah, mas eu não sou homossexual. Sou garoto de programa. Eu só transo com eles, porque a crise me levou a isso, eu tinha emprego, trabalhava num banco, estudava, era evangelista cristão".

Observa-se nesse relato um tipo de experiência pessoal expressa em: "eu tinha emprego, trabalhava num banco, estudava, era evangelista cristão". Há no discorrer da experiência, a menção a uma referência pessoal configurada em termos de solidez e credibilidade para os fatos apresentados. O participante explica-se, recorrendo a um tipo de credencial para justificar e validar suas estórias. Preocupase em demonstrar que foi impelido a esse tipo de prática sexual por razões econômicas, porém essa preocupação é sustentada por argumentos para encobrir a possibilidade de uma prática sexual homoerótica: "Ah, mas eu não sou homossexual". Registra-se também um tipo de orientação que objetiva identificar uma situação de vida anterior e também evidenciar traços identitários do narrador. Em certo sentido, o narrador atribui sua mudança de situação de vida a acontecimentos externos como a crise causada pelo desemprego.

Garoto de programa: "Aí perdi meu emprego; fiquei sem dinheiro. Tenho um carro que tá em casa porque não tenho dinheiro pra botar gasolina; depois que eu entrei pra Marinha, eu ouvi uns caras dizendo que tem esses homens que procuram a gente". 
Em virtude de o presente ser uma situação difícil, a busca do passado é uma proteção defensiva como podemos depreender em: "Aí perdi meu emprego; fiquei sem dinheiro", o que evidencia índices de uma ação complicadora. Não obstante, a proteção referida ao passado perde sua eficácia em relação a uma situação de carência do presente. A perda do emprego é a justificativa plausível que autoriza o ingresso em um tipo de submundo onde ocorrem práticas sexuais que são repudiadas, como também a satisfação que delas decorre evidenciadas na passagem: "Tenho um carro que tá em casa porque não tenho dinheiro pra botar gasolina”. Deduz-se assim que o garoto de programa, ao fazer uma avaliação de sua situação de vida, tem clareza de suas perdas em termos da condição socioeconômica. Desse modo, o foco de sua narração passa por uma mudança para situar a condição de sua vida presente e também demonstrar a intensidade da crise; isso aliado à construção de argumentos utilizados para isenção de culpa e de responsabilidade pelo ingresso no âmbito da prostituição, conforme encontramos em: "depois que eu entrei pra Marinha, eu ouvi uns caras dizendo que tem esses homens que procuram a gente". A ciência da possibilidade de obtenção de dinheiro aparece como uma espécie de resolução em função da qual passa a adotar dados tipos de alternativas de vida de outras pessoas, sem antes refletir sobre as consequências dessas alternativas em relação às suas escolhas e seu projeto de vida. O ingresso na Marinha é o ponto que constitui a resolução para a ação anterior "perdi meu emprego". Porém, na realidade, é a condição desencadeadora de um novo conflito evidenciado pela entrada em cena do antagonista: "esses homens que procuram a gente". Esses antagonistas são responsabilizados, pelo garoto de programa, pelos seus sofrimentos e conflitos em uma espécie de deslocamento e projeção. Daí então se utiliza de um mecanismo protetor para não tomar contato com o fato de que transa com homens, retirando de cena o seu desejo: "são os homens quem procuram" e não o próprio que decidiu praticar tais ações. Logo, se há um culpado por tais vilezas, esse é o cliente. O garoto de programa isenta-se de culpa, com argumentos cabais, também para os possíveis desdobramentos que possam ocorrer, caso haja quebra do contrato.

Garoto de programa: "No início tive pena deles. São muito infelizes, devem ser muito problemáticos, porque são muito promíscuos. Esses homossexuais são dignos de pena". 
A vontade para a prática de ações condenadas é localizada nos antagonistas, objeto de repúdio e ódio, responsabilizados por ações, as quais o garoto de programa julga ser obrigado a realizá-las, como roubo, assalto, ameaça entre outras. Não obstante, os sentimentos são contraditórios como em: "no início tive pena deles". Desse modo, o garoto de programa caracteriza o antagonista das práticas sexuais em que se engaja como homens desprovidos de qualidades morais e dignidade em: "são muito infelizes, devem ser muito problemáticos, porque são muito promíscuos. Esses homossexuais são dignos de pena". Esse tipo de explicação sobre o antagonista serve para demarcar um distanciamento identificatório do protagonista no que concerne à questão da homossexualidade e também à possibilidade de pertencerem a mundos diferentes em termos de valores morais, uma vez que condenam tais sujeitos sob a alegação de que são promíscuos. Também o garoto de programa não se reconhece no antagonista em relação ao fato de que, também, tem relações sexuais com homens. O apelo a um recurso em direção a uma heterossexualidade compulsória é constante na avaliação feita pelo garoto de programa, quando apresenta suas credenciais como homem que gosta de mulher; que só sente satisfação quando transa com mulher e que não é homossexual. Esse recurso alicerça-se

na essencialização do alinhamento entre sexo, gênero e desejo: a suposição da determinação linear do sexo biológico sobre a apresentação social do masculino pressupõe a definição de objeto de desejo como sendo de sexo oposto ao daquele que deseja (LIONÇO e DINIZ, 2008:315).

Munido dessa concepção, o protagonista avalia positivamente as suas ações e, negativamente, as do antagonista.

Garoto de programa: "Depois, o senhor sabe, de tanto eles passarem de carro por lá, e minha necessidade, eu acabei entrando nesse submundo nojento. Agora tou nessa, porque tou sem dinheiro. É só por dinheiro. Tenho certeza que se eu tivesse dinheiro, não tava nessa. Eu acho que a pessoa deve transar porque gosta e não por causa do dinheiro. Eu acho isso certo. O homossexual tá errado, ele contraria tudo. Acha porque tem dinheiro, pode fazer o que quer com o garoto de programa".

No entanto, o protagonista demonstra, de forma clara, a sua impotência, em relação à tentação do antagonista, o que se configura como um tipo de resolução. 
Observemos essa evidência na passagem: "depois, o senhor sabe, de tanto eles passarem de carro por lá, e minha necessidade, eu acabei entrando nesse submundo nojento". Finalmente curva-se diante das circunstâncias que julga tê-lo levado a esse tipo de ação: “agora tou nessa". Esse possível desfecho traz o narrador de volta ao ponto anterior à sua entrada na narrativa, conforme se depreende em: "porque tou sem dinheiro. É só por dinheiro. Tenho certeza que se eu tivesse dinheiro, não tava nessa". O foco da pergunta "esses homens que transam por dinheiro" provoca, no garoto de programa, sentimentos contraditórios que o levam a justificar seu engajamento nessa atividade, desresponsabilizando-se e desculpando-se como em: "eu acho que a pessoa deve transar porque gosta e não por causa do dinheiro". Assim admite o desejo quando afirma que as pessoas devem transar por que gostam, mas se isenta de admiti-lo quando faz entrar em cena o dinheiro. Eis um indício do conflito em que se encontra, mas que sequer tem clareza, pois se expressa em termos de uma suposição e não de uma convicção. Trata-se, sem dúvida, do dilema explicitado em relação a um tipo de escolha, transar por amor ou transar com homens para obter dinheiro. Essa última possibilidade contraria valores morais, especialmente oriundos da filiação ao cristianismo, conforme se evidencia em "ainda tem muito grilo na minha cabeça". Porém justifica a crise e a falta de dinheiro como condições que o deixa sem opções, atribuindo-lhes certa imperiosidade, a qual the resta cumprir, mesmo que discorde. Mas, em nenhum momento, mostra-se afeito a aceitar que sua relação sexual, com os clientes, é de natureza homoerótica, embora saiba que recebe dinheiro pelo aluguel de seu corpo jovem revestido das insígnias militares que confere, para alguns homens, o valor de fetiche (ASSOUN, 2006). A saída que encontra para conviver com esse dilema, de forma menos conflituosa, é colocar-se na posição de vítima de uma situação econômica e contar com homens dispostos a pagar por satisfações sexuais. Ao colocar-se na posição de vítima reconhece a condição homossexual apenas no antagonista, sob uma forte condenação e repúdio, sem aventar a possibilidade de estar na mesma condição e que ganhar dinheiro transando com homens tem certa atratividade para si mesmo. Desse modo, abomina qualquer possibilidade de satisfação nesse tipo de atividade sexual mediada pelo dinheiro, até mesmo em relação aquilo que pode usufruir. Quer dizer, parece não aceitar que o dinheiro dessas incursões tem serventia para suprir algumas de suas necessidades que, em suas palavras, evidenciaram-se com a perda do emprego e a crise. 


\subsection{Eixo 2: A satisfação e o prazer na atividade de prestação de serviços sexuais}

Pesquisador: "Na relação com eles você goza?"

Garoto de programa: "Ah, eu gozo porque eles querem. Eles pagam por isso e depois eu tenho muita raiva deles. Sabe, tem um tio meu, irmão de minha mãe, que é homossexual. Ele vivia lá em casa, mas começou a usar drogas e minha mãe botou ele pra fora de casa. Ele arrumou um italiano e aprendeu a falar várias línguas. Eu não tinha raiva dele. Hoje eu tenho, porque sei que ele é infeliz".

A narrativa demonstra uma experiência vicária que remonta à sua história pessoal, em um tipo de resgate de uma memória referida à condição de ancestralidade, conforme se constata em: "sabe, tem um tio meu, irmão de minha mãe, que é homossexual. (...) Eu não tinha raiva dele. Hoje eu tenho, porque sei que ele é infeliz". Evidencia-se dois tipos de afetos, a raiva e a pena, que não encontram soluções em suas ações, sugerindo, assim, polaridades que, ora recaem no ódio, ora recaem na culpa. Além disso, configura-se uma situação de transmissão de um protocolo de memória (POLLAK, 1992), acerca da possibilidade de que uma orientação sexual, considerada socialmente marginal, pode ser vantajosa "Ele arrumou um italiano e aprendeu a falar várias línguas".

\subsection{Eixo 3: O contrato do encontro para prestação de serviços sexuais}

Pesquisador: "Quando você transa com esses caras, o que você sente?"

Garoto de programa: "Eu faço o que eles querem. Se eu gozo é porque é preciso, se não o serviço não fica completo e aí eles não querem pagar. Eles não querem nem saber o que a gente sente, quem nós somos. Tratam a gente como qualquer coisa, só porque a gente é pobre... eles tratam a gente como se nós fosse bicho".

Se compararmos as perguntas de abertura do eixo 2, "na relação com eles você goza" com a pergunta de abertura do eixo 3, "quando você transa com esses caras, o que você sente?" e suas respectivas respostas, constatamos que a parte inicial da resposta à pergunta de abertura do eixo 3 "eu faço o que eles querem", constitui uma retomada da pergunta de abertura do eixo 2: "na relação com eles 
você goza". Além disso, enquanto o pesquisador, na pergunta de abertura do eixo 3 , quer saber o que o protagonista sente ao transar com homens por dinheiro, responde de forma indireta: "eu faço o que eles querem", descrevendo, desse modo, a maneira como o antagonista age para exigir que determinadas coisas sejam feitas, como o orgasmo. Analisando essas questões em relação à satisfação, observa-se que o garoto de programa é bastante enfático ao afirmar que a satisfação acontece para atender a uma cláusula do contrato: goza porque eles querem e estão pagando por isso. Desse modo, esquiva-se em reconhecer sua satisfação, pelo menos em relação à obtenção de dinheiro. Há, também, outro nível de interpretação, pois ao imputar todo o comando de ações às exigências do cliente, o protagonista não admite ter feito uma escolha para ingressar no universo dessas atividades. Sendo assim, a posição de vítima é uma desculpa para justificar a prática de relação sexual com homem por dinheiro: o relato é um pano de fundo para revelações e mudança de atitudes, doravante, admitidas e assumidas.

Garoto de programa: "Se gozo é porque gosto".

Em primeiro lugar, suas atividades e seus desejos não aceitos se põem a descoberto em função do fato de que transa com homens, mesmo que condene afirmando que: "se gozo é porque gosto". Vê-se assim que a contradição apresentada anteriormente entre gostar de transar com quem deseja e transar por dinheiro está bem evidente. Provavelmente com o desenrolar dos encontros com o pesquisador adveio um tipo de confiança para fazer esse tipo de confidência: gostar do que faz. A assunção, pelo garoto de programa, de que gosta porque goza não quer dizer que, com isso, seja admitida qualquer possibilidade de uma prática sexual de natureza homossexual.

Garoto de programa: "Aconteceu uma coisa chata. Um coroa, um senhor, sabe?, me levou um lanche, isso foi logo cedo. Aí o oficial do dia viu. Aí a coisa não prestou! Ele me chamou. Eu fiquei doidinho porque aí ele soube de tudo. Eu ia pegar dez dias de cadeia. Fiquei muito descontrolado! Ele me chamou lá, e eu disse que era um amigo. Eu sei que ele não acreditou, mas precisava dizer. Nesta noite, eu tive vontade de apontar o fuzil para todos que passavam lá. Teve hora que passou um. Aí, eu disse: 'se você não for embora logo eu atiro em seus pneus'”.

Em segundo lugar, o garoto de programa direciona sua narrativa para evidenciar uma complicação decorrente de um episódio na situação de prestação de serviços sexuais: "aconteceu uma coisa chata. Um coroa, um senhor, sabe?, me 
levou um lanche, isso foi logo cedo. Aí o oficial do dia viu. Aí a coisa não prestou! Ele me chamou. Eu fiquei doidinho porque aí ele soube de tudo". Desse modo, acredita que seu suposto segredo estaria revelado ao seu superior imediato. Daí emergiu um tipo de sentimento negativo com explosão de agressividade sob a forma de ameaça: "Se você não for embora logo eu atiro em seus pneus", porém sob certo controle. Na verdade, a expressão "eu fiquei doidinho" revela o seu temor quanto à possibilidade de julgarem-no homossexual e assim perder, para si próprio, o estatuto de heterossexual compulsório que acredita ter.

Garoto de programa: “Isso não podia ter acontecido comigo. Eu ter caído nessa vida. Se tivesse dinheiro, não tava nessa. É só por necessidade. Mas o pior é que quando deixo fazer o 'boquete', eu gozo. Se não gostasse, eu não gozava. Então, se eu gozo, a coisa não devia ser por dinheiro. Mas o problema é que eles têm dinheiro e eu não tenho".

Em terceiro lugar, o contexto direciona-se para uma atitude de lamentações: "isso não podia ter acontecido comigo. Eu ter caído nessa vida. Se tivesse dinheiro, não tava nessa. Mas o pior é que quando deixo fazer o ‘boquete’ (felação), eu gozo. Se não gostasse, eu não gozava”. Depreende-se dessa passagem uma dupla revelação: a descoberta de suas atividades que ele supunha serem secretas e a ciência de gostar do que faz. Além disso, expressa também uma contradição em relação ao seu sistema de valores: gozar por prazer e goza r por dinheiro. Admite que se há prazer no sexo, então não deveria cobrar pelo que faz e se cobra é porque aqueles que o procuram têm dinheiro. Sua constatação de que gosta do que faz invalida a cláusula de que o gozo é uma exigência do contrato. Sendo assim, fica insustentável o argumento do dinheiro para tais atividades.

Garoto de programa: "Eu sempre pensei em pescar com meu pai. Ter alguém para conversar comigo. Acho que porque meu pai é fechado. Eu acabo fazendo essas coisas".

Há claramente uma mudança de orientação quando desloca a responsabilidade por suas escolhas e sua orientação homossexual para seu pai, revelada em: "Eu sempre pensei em pescar com meu pai. Ter alguém para conversar comigo. Acho que porque meu pai é fechado. Eu acabo fazendo essas coisas". É importante salientar que sempre encontra um agente externo para responsabilizá-lo pelas suas ações e consequentemente por seus sentimentos. Apresenta um estado de carência paterna como sendo a causa de sua solidão e 
também pelo fato de que é levado a determinas ações, ou seja, se o pai não o protege fica então à deriva, sem saber qual rumo deverá tomar. Há nisso um tom de lamentação e de carência, em termos de um modelo identificatório com o pai.

\subsection{Eixo 4: A percepção do garoto de programa ao desempenhar este papel}

Pesquisador: "Quando você sai com esses caras, você combina alguma coisa?".

Garoto de programa: "Ah, sim. É só o boquete (felação). E pronto. Nada de penetração, porque isso é para xibungo (gíria utilizada entre marinheiros para homossexual). Além do mais, eles aceitam qualquer coisa. Depois que gozam... ficam doidos para se livrar da gente".

Pesquisador: "E se o coroa não te pagar, o que você faz?".

Garoto de programa: "Eu sou capaz de encher ele de porrada e tomar tudo o que ele tem. Não que eu seja disso, mas eu sou capaz de matar, porque se eles vão ali mexer com quem está quieto, não pode vacilar. Outro dia eu entrei num carro. $O$ coroa veio com umas ideias. Eu disse que era 50 o boquete. E ele ofereceu 10 e queria me comer. Aí, eu disse: 'dá a volta e me deixa se não eu te encho de porrada'. Aí, ele me deixou. Eu tive muita raiva dele. Deu vontade de bater nele. Eu acho que é por isso que meus colegas combinam com os paisanas (policiais) e fazem assaltos. Eu nunca fiz, mas tem coroas que merecem ser assaltados para aprender a deixar de ser otário".

A explicitação do ódio, nessa circunstância, é justificada em continuidade com a narração de um episódio que tem, para ele próprio, duas finalidades: demonstrar do que é capaz, caso seja contrariado e que se o cliente não cumpre o contrato, isto é interpretado pelo garoto de programa, como o pedido de outros tipos de ocorrências: espancamento, aviltamento, roubo. Quer dizer, interpreta a quebra de contrato como um pedido do cliente para obter prazer pela dor e ser rebaixado conforme o trecho seguinte ilustra: "tem coroas que merecem ser assaltados para aprender a deixar de ser otário". Há nisso também a presunção de isenção de responsabilidade pelos outros tipos de ações que o garoto de programa venha praticar: se o cliente vacila, então quer sofrer, ser roubado, ser maltratado e humilhado (FREUD, 1976). 
Garoto de programa: "Olha, eu nunca fiz nada com ninguém, mas um dia desses eu vou ensinar um desses coroas qual é o caminho da vida. Hoje, eu cheguei primeiro que o senhor, tava querendo contar umas coisas que eu acho que o senhor quer saber sobre a sua pesquisa. Eu disse que só transava por dinheiro e que tava nessa por necessidade. Aí, apareceu lá no quartel um empresário. Ele é de São Paulo, tem muito dinheiro e tem um AP (quitinete) em Copacabana... Aí, os caras me botaram no telefone pra falar com ele... e aí, ele marcou pra se encontrar comigo. Eu fui no AP dele. Aí, ele disse pra mim: 'como é bom ser rico! Pobre não tem gosto, nem vive, apenas passa pela vida'. Aí, eu disse pra ele: 'mas eu sou pobre, eu vim de família humilde'. Ele disse: 'mas você é diferente'. Diferente coisa nenhuma. Me vesti e fui embora e não quis mais saber de carro, nem dele. Naquela hora me deu uma raiva dele tão grande, que se tivesse uma arma eu mataria aquele cara. Ele tá pensando só porque é rico pode humilhar os pobres. Descobri que aquele cara é igualzinho aos outros. Ele faz o que os outros fazem. Eles não pensam na gente. Vocês só querem usar a gente e largar como se larga um cachorro. Eu sinto falta de alguém para pescar comigo".

O garoto de programa, embora não faça maldades, acredita que os clientes merecem ser castigados ao não respeitarem as cláusulas do contrato: "Olha eu nunca fiz nada com ninguém, mas um dia desses eu vou ensinar um desses coroas qual é o caminho da vida". No prosseguir dos encontros, o garoto de programa faz uma revelação para si mesmo, tomando a iniciativa de dirigir o curso da narrativa determinando a temática de abertura: "hoje, eu cheguei primeiro que o senhor, tava querendo contar umas coisas que eu acho que o senhor quer saber sobre a sua pesquisa. Eu disse que só transava por dinheiro e que tava nessa por necessidade". Ainda nesse trecho, em função de um vetor transferencial, o garoto de programa equipara o pesquisador aos seus clientes quando afirma: "Vocês só querem usar a gente e largar como se larga um cachorro". A esta altura da relação estabelecida pela transferência de trabalho, observa-se um ato falho em que o garoto de programa inclui o pesquisador no rol de seus supostos clientes ao utilizar-se do pronome vocês. Inconscientemente, coloca no mesmo plano homens que o querem para práticas sexuais e o pesquisador que o procura em função do saber, em práticas discursivas. Considerando esses pormenores, indaga-se: aquilo que 0 pesquisador está querendo saber será, finalmente, revelado pelo garoto de programa?, conforme sugere a passagem: "eu disse que só... mas não é verdade", 
ou mais precisamente "e é verdade". Vê-se assim que essas questões são deixadas em aberto, porém servem para que o garoto de programa reafirme para si mesmo que é uma boa pessoa, sensível enquanto que o cliente é visto como insensível e mau porque tem dinheiro e que por isso humilha as pessoas. Essa disjunção e outras como homossexual e não homossexual, em relação a homens que fazem sexo com homens, é uma constante em sua produção discursiva.

\section{Reflexões conclusivas}

O contrato estabelecido entre o garoto de programa e o cliente não transforma esses protagonistas em aliados devido à assimetria dessa relação em relação às condições e posições subjetivas diferenciadas: a situação econômica do cliente (rico) e a do garoto de programa (pobre); a posição masculina do garoto de programa exigida nas atividades sexuais para a manutenção da postura de ativo sexual; o cliente deve assumir a posição de passivo sexual; a faixa etária, jovem como objeto de beleza, virilidade e prazer; a faixa etária do cliente marcada pela carência desses mesmos elementos, compensada pela sua situação econômica; o garoto de programa apresenta-se como detentor de algo que falta ao cliente, colocando-se na posição de credor e merecedor de recompensa: o ato sexual não redunda apenas em retribuição financeira, deve incluir consideração e reconhecimento; e, parece haver uma estratégia no contrato de que determinadas ações, de cunho puramente sádicas, são apenas do encargo do garoto de programa. Por outro lado, o garoto de programa vê o cliente como o responsável direto pelo seu suposto sacrifício de transar com homens por dinheiro e autoriza-se a considerá-lo adversário e agressor que the inflige sofrimentos e humilhações, causador de seus conflitos morais, sociais e existenciais, além de responsável por fazer desapontar em si (garoto de programa) sua orientação homossexual.

Desse lugar de vítima degradada pelos infortúnios de suas condições pessoais, nada mais justo defender-se e vislumbrar meios para livrar-se de seu agressor, mesmo que não faça tais coisas: diferentemente de colegas de prestação de serviços sexuais que roubam, assaltam e participam de montagens criminosas com agentes policiais em desvio de suas funções. Não pratica tais atos, embora não os desaprove. Acredita que esses homens morrem porque são promíscuos, 
deixando clara a condenação e ódio ante a obtenção de prazer em práticas sexuais que não estejam a serviço da reprodução.

As interpretações e análises fundamentam-se nas circunstâncias do contrato para prestação de serviços sexuais. Para tanto, o garoto de programa valeu-se da narrativa em que predominam elementos avaliativos para comparar situações, ações, valores e justificar atitudes e sentimentos. Quase todos os elementos contribuem para a compreensão de que o autor da escrita a produz visando a uma valorização positiva de si mesmo. Cada elemento da narrativa tem duas facetas: apresentar o garoto de programa na condição de quem é bom e o cliente como mau. Assim, justifica para si mesmo sua expectativa subjacente de que todo erro, no caso, a relação sexual entre homens por dinheiro ou sem, merece castigo, principalmente para quem a procura. Há, finalmente, um aspecto a ser considerado. O garoto de programa apresenta um questionamento em relação às definições pautadas em dados critérios: tem convicção de que é heterossexual e transa com homens por dinheiro e não porque deseja, embora goste. 


\title{
SECRET ACTIVITIES IN SHADY NIGHTS: MEMORIES OF RENT BOYS' UNIVERSE
}

\begin{abstract}
This paper aims at explaining the relationship between two types of sexual activities, taken as actions performed in certain places by a man who offers his body for sexual services for temporary rent, identified here as the landlord, and the other who often goes to these places searching for those services, identified here as the tenant. Both agree on a contract put forward by the landlord; the tenant, thus, might accept it or not, but he shall never change any of its clauses. The researcher has written down the actions of both men reported by the landlord along five meetings, which constitutes a register about many episodes that take place in the shadows and silences of the night in big cities where male prostitution occurs. It is assumed that this contract does not make them partners due to the asymmetrical relationship created between two distinct subjective positions. Also, the paper highlights that the landlord uses excuses to deny his homosexuality.
\end{abstract}

Keywords: Homosexuality. Prostitution. Social memory. Crime. Desire

\section{ACTIVIDADES SECRETAS EN NOCHES SOMBRÍAS: MEMORIAS DEL UNIVERSO DE LOS MUCHACHOS QUE ALQUILAN SU CUERPO}

\section{Resumen}

Este estudio pretende explicar las relaciones entre dos tipos de actividades sexuales, caracterizadas como la acción de un hombre en determinados lugares para ofrecer y prestar servicios sexuales, disponiendo del cuerpo para alquiler temporal, identificado como propietario $y$, la de otro que frecuenta esos lugares buscando tales servicios, identificado como inquilino. Ambos celebran un contrato determinado por el propietario, restando al inquilino aceptarlo o no, pero jamás modificar alguna de las cláusulas. La acción de esos hombres y sus consecuencias relatadas por el propietario en cinco encuentros, anotados por el investigador, constituyen un texto sobre varios acontecimientos que tienen lugar en el silencio de las noches en los espacios de las grandes ciudades donde ocurre la prostitución masculina. Se concluye que el contrato entre ambos no los transforma en aliados debido a la asimetría de la relación que se establece entre dos posiciones subjetivas diferentes, y que el propietario utiliza subterfugios para negar su homosexualidad.

Palabras clave: Homosexualidad. Prostitución. Memoria social. Crimen. Deseo. 


\section{Referências}

ALVES, A. L. Garotos explorados sexualmente: uma violação dos direitos humanos. In: RODRIGUES, A. S.; BRUNETTO, G.; BROTTO, M. E. (orgs.) Os hereges. Porto Alegre: Armazém Digital, 2010, pp. 32-38.

ARRUDA, R. Dias de ira. Rio de Janeiro: Globo, 2001.

ASSOUN, P-L. Le fetichisme. Paris: PUF, 2006.

BUSSINGER, R. Corpo gênero e identidade em Madame Satã. Psicologia Política. 11 (21), 2011, pp. 91-107.

BUTLER, J. Problemas de gêneno. Rio de Janeiro: Civilização Brasileira, 2010.

FARIAS, F. R. Esse olho que olha... mata! Tempo Psicanalítico. Rio de Janeiro: 28, 1995, pp. 135-153.

FREUD, S. Uma criança é espancada: uma contribuição ao estudo da origem das perversões sexuais. In: Obras Completas. Rio de Janeiro: Imago, v. XVII (original publicado em 1919), 1976, pp. 223-253.

LIONÇO, T.; DINIZ, D. Homofobia, silêncio e naturalização. Psicologia Política. 11 (21), 2008, pp. 307-324.

LUMBROSO, P. Libre d'être putain? Paris: Harmattan, 2008.

MOTT, L. Os homossexuais: as vítimas principais da violência. In: VELHO, G.; ALVITO, M. (orgs.) Cidadania e violência. Rio de Janeiro: UFRJ/FGV, 1996, pp. 99144.

NARDI, H. C. Sexo e poder nas tramas pós(?)identitárias: reflexões sobre a prostituição masculina. In: LOPES, L. P. M.; BASTOS, L. B. (orgs.) Para além da identidade. Belo Horizonte: Editora UFMG, 2010.

PARKER, R. Empoderamento erótico e cidadania sexual para homens que fazem sexo com homens e tribos afins. In: RIO, L. F. (org.) Homossexualidade, produção cultural, cidadania e saúde. Rio de Janeiro: Abia, 2004. 
PERLONGHER, N. O negócio do michê. São Paulo: Fundação Perseu Abramo, 2008.

POLLAK, M. A homossexualidade masculina, ou a felicidade no gueto. In: ARIĖS, P.; BEJIN, A. (orgs.) (1986). Sexualidades ocidentais. São Paulo: Brasiliense, 1986.

POLLAK, M. Memória e identidade social. Estudos históricos. Rio de Janeiro: 5, (10), 1992, pp. 200-212.

RIESSMAN, C. K. Narrative methods for the human sciences. New York: Sage Publications, 2008.

SADE, M. A filosofia na alcova. São Paulo. lluminuras, 2008.

SAFOUAN, M. Somente há um sujeito que fala: Psicanálise e interdisciplinaridade. In: WEIL, D. (org.) O homem e o sujeito. Rio de Janeiro: Revinter, 2001, pp. 75-95.

STOLLER, R. Masculinidade e feminilidade. Porto Alegre: Artmed, 1993.

Artigo:

Recebido em: Agosto/2012

Aceito em: Abril/2013 